Ewa K. Czaczkowska ${ }^{1}$

Uniwersytet Kardynała Stefana Wyszyńskiego

\title{
Kłopoty z kultem Bożego miłosierdzia w korespondencji Marii Winowskiej w latach 1958-1975
}

W Archiwum Kurii Metropolitalnej w Krakowie przechowywane jest prywatne archiwum Marii Winowskiej ${ }^{2}$, wybitnej katolickiej pisarki, działaczki emigracyjnej, przez lata bliskiej współpracownicy prymasa Stefana Wyszyńskiego. Wśród dokumentów znajduje się m.in. korespondencja z wybitnymi postaciami Kościoła, dotycząca kultu Bożego miłosierdzia w formach podanych przez s. Faustynę Kowalską. Listy, które zostaną omówione w niniejszym artykule, były pisane w latach 1958$1975^{3}$. Rozpoczynają się zatem w niezwykle gorącym okresie dla czcicieli Bożego miłosierdzia. 19 listopada 1958 roku Święte Oficjum w przyjętym dekrecie m.in. zakwestionowało nadprzyrodzoność objawień s. Faustyny,

1 Ewa K. Czaczkowska - doktor historii, publicystka, adiunkt w Instytucie Edukacji Medialnej i Dziennikarstwa UKSW w Warszawie, członek zespołu redakcyjnego Pro memoria prymasa Stefana Wyszyńskiego. Autorka książek m.in. Prymas Wyszyński. Biografia, Siostra Faustyna. Biografia świętej, Ksiądz Jerzy Popiełuszko (wspólnie z Tomaszem Wiścickim). E-mail: e.czaczkowska@areopag21.

2 AKMKr, archiwum Marii Winowskiej jest nieskatalogowane.

${ }^{3} \mathrm{~W}$ artykule omówiona jest korespondencja Marii Winowskiej z polskimi adresatami. Listy, których adresaci nie zostali zidentyfikowani, zostały pominięte. W przygotowaniu jest omówienie listów w j. francuskim. 
zakazując rozpowszechniania obrazków i pism propagujących nabożeństwo do Bożego miłosierdzia w formach przekazanych przez s. Faustynę oraz dało poważne ostrzeżenie ks. Michałowi Sopoćce, nakazując, aby „zaprzestał obrony i propagowania tych objawień i nabożeństw”. 6 marca 1959 roku Święte Oficjum opublikowało łagodniejszą w treści od dekretu notyfikację, w której zakazało rozpowszechniania obrazów i pism propagujących nabożeństwo do Bożego miłosierdzia, natomiast „roztropności biskupów” oddano decyzję o usuwaniu z kościołów obrazów Jezusa Miłosiernego ${ }^{4}$. Korespondencja dotycząca rozwoju kultu Bożego miłosierdzia kończy się w 1975 roku, czyli na trzy lata przed odwołaniem przez Kongregację Nauki Wiary notyfikacji z 1959 roku.

Maria Winowska była sprawą rozwoju kultu Bożego Miłosierdzia żywotnie zainteresowana. Jako autorka pierwszej biografii s. Faustyny ${ }^{5}$, wydanej w Paryżu w kwietniu 1958 roku, a zatem kilka miesięcy przed przyjęciem przez Święte Oficjum dekretu, była przekonana o prawdziwości objawień polskiej mistyczki i o potrzebie rozwoju kultu Bożego miłosierdzia w dzisiejszym świecie.

Celem artykułu jest ukazanie korespondnecji, jaką Maria Winowska prowadziła w latach 1958-1975 z wieloma postaciami Kościoła w sprawie kultu Bożego miłosierdzia, próbując na różne sposoby wpłynąć na rozwiązanie sytuacji spowodowanej dekretem i notyfikacją watykańskiej kongregacji. Na początku przedstawię bohaterów korespondencji, przybliżając nieco postać Marii Winowskiej. Następnie dokonam opisu źródeł, po czym przejdę do szczegółowego omówienia korespondencji Marii Winowskiej z ks. Michałem Sopoćką, abp. Józefem Gawliną, abp. Antonim Baraniakiem, s. Beatą Piekut, abp. Karolem Wojtyłą i ks. Julianem Chróściechowskim.

4 E. K.Czaczkowska, Siostra Faustyna. Biografia Świętej, Kraków 2012, s. 346.

5 M. Winowska, Droit à la miséricorde. Vie et mission de soeur Faustine du Saint Sacrement de Pologne, Paris 1958. 


\section{Maria Winowska - autorka korespondencji}

Maria Winowska ${ }^{6}$, urodzona w 1904 roku w Skałacie w województwie tarnopolskim, po ukończeniu filologii romańskiej, klasycznej oraz filozofii na Uniwersytecie Jana Kazimirrza we Lwowie, uzyskała doktorat z filozofii i teologii. W czasie II wojny światowej m.in. działała we francuskim ruchu oporu, współpracowała z przebywającym we Francji kard. Augustem Hlondem. Po wojnie mieszkała w Paryżu, w klasztorze sióstr nazaretanek. Pisała o postaciach ważnych w historii Kościoła, o świętych, o Kościele za żelazną kurtyną, często pod pseudonimami. Miała szerokie kontakty w środowisku dysydentów z Europy środkowo-wschodniej oraz w kołach katolickich wielu krajów. Przez długie lata współpracowała z kard. Stefanem Wyszyńskim, z którym spotykała się w Rzymie, prowadząc jego korespondencję. Jan Nowak-Jeziorański, dyrektor Rozgłośni Polskiej Radia Wolna Europa, który z Winowską był w kontackie listowym od roku 1955 do 1989, wspominał: „Dzięki świetnej znajomości języków miała rozległe stosunki zarówno w Episkopacie francuskim, jak i niemieckim. W Watykanie pozostawała w bardzo bliskim kontakcie z kapelanem Pawła VI. Wiem, nie od niej, lecz od osób z otoczenia Prymasa, że wykorzystywał on ten kontakt do załatwiania wielu spraw, często ponad głową Sekretariatu Stanu"?.

Maria Winowska była autorką 38 książek tłumaczonych na wiele języków, w tym tak znakomitych biografii jak o. Maksymiliana Kolbego, o. Pio czy wspomnianej już s. Faustyny Kowalskiej. W Polsce ta książka ukazała

6 Noty biograficzne, wspomnienia w: J. Nowak-Jeziorański, M. Winowska, Korespondencja 1955-1989, oprac. i wstępem opatrzył A. Nowak, Wrocław 2016, s. 10-13; J. Winowska, Maria Winowska, Kraków 1995, mps.; M. K. Rottenberg, Aby byli jedno, Warszawa 2005, s. 451; A. Boniecki, Odczyt, którego nie będzie, „Tygodnik Powszechny” 1993, nr 22, s. 6; J. Turowicz, Maria Winowska nie żyje, „Tygodnik Powszechny” 1993, nr 22, s. 1; E. K Czaczkowska, Nowe ustalenia w sprawie listów milenijnych biskupów polskich do episkopatów świata. Maria Winowska i kard. Stefan Wyszyński współautorami listów, w: 1966. Milenium chrztu Polski prymasa Stefana Wyszyńskiego. Perspektywa teologiczno-społeczna, Warszawa 2016, s. 131150; H. Konopkowa, Marii Winowskiej refleksje nad życiem, http://www.cracovia-leopolis.pl/ index.php?pokaz=sylwetki\&id=310 (27.01.2018); E. K. Czaczkowska, Maria Winowska - szara eminencja Kościoła, „Gość Niedzielny” 2016, nr 13. s. 24-25.

J. Nowak-Jeziorański, M. Winowska, Korespondencja 1955-1989, dz. cyt., s. 8. 
się dopiero w 1974 roku pod tytułem Prawo do miłosierdzia. Posłannictwo Siostry Faustyny. Winowska zmarła w Paryżu w 1993 roku.

\section{Inni autorzy listów}

Wśród polskich autorów korespondencji z Marią Winowską na temat rozwoju kultu Bożego miłosierdzia są: ks. Michał Sopoćko (1988-1975) ${ }^{8}$ ojciec duchowy, spowiednik s. Faustyny, zabiegający o ustanowienie święta Bożego miłosierdzia; s. Beata Piekut (1907-2007) ${ }^{9}$ ze Zgromadzenia Sióstr Matki Bożej Miłosierdzia, wicepostulatorka w procesie kanonizacyjnym s. Faustyny Kowalskiej; ks. Julian Chróściechowski (?-1976) ${ }^{10}$ marianin, pierwszy przełożony prowincji NMP Matki Miłosierdzia w Anglii. Są w zbiorze także listy od abp. Józefa Gawliny (1892-1964) ${ }^{11}$, mieszkającego w Rzymie opiekuna duchowego Polaków na emigracji, abp. Karola Wojtyły (1920-2005) ${ }^{12}$ oraz kopia listu do abp. Antoniego Barniaka (1904-1977) ${ }^{13}$, metropolity poznańskiego.

\section{Opis źródeł}

W spuściźnie Marii Winowskiej zachowały się cztery listy ks. Michała Sopoćki - z 27 maja 1958 roku, 17 marca 1959 roku, 23 kwietnia 1959 roku, 7 lipca 1959 roku - oraz kopie dwóch listów Winowskiej do ks. Sopoćki:

8 H. Ciereszko, Życie i działalność księdza Michała Sopoćki (1888-1975). Pełna biografia Apostoła Miłosierdzia Bożego, Kraków 2006.

9 E. K. Czaczkowska, Siostra Faustyna, s. 182-183.

10 Zob. E. Weron, F. Cegiełka, Biuletyn teologii laikatu, „Collectanea Theologica” 52 (1982) 1, s. 137-156.

11 Zob. Józef Feliks Gawlina Biskup Polowy Polskich Sił Zbrojnych, w: Emigracyjna Rzeczpospolita 1939-1990, t. 3. oprac. A. K. Kunert, Warszawa 2002.

12 Literatura jest nader obfita. Najpełniejszą biografię stanowi praca G. Weigla, Świadek nadziei. Biografia papieża Jana Pawła II, tłum. M. Tarnowska i in., Kraków 2000 oraz jej uzupełnienie: Kres i początek. Papież Jan Paweł II - zwycięstwo wolności, ostatnie lata, dziedzictwo, przeł. M. Romanek, Kraków 2012.

13 Zob. Wprowadzenie, w: M. Jędraszewski, Teczkina Baraniaka, t. 1, Świadek, Poznań 2009, s. $17-24$. 
z 21 czerwca 1958 roku oraz 4 marca 1959 roku (ten dokument jest niedatowany, ale datę podał ks. Sopoćko w odpowiedzi z 17 marca 1959 roku). Są w zbiorze także cztery listy ks. Juliana Chróściechowskiego do Marii Winowskiej - z 3 grudnia 1967 roku, 21 kwietnia 1969 roku, 20 stycznia 1970 roku, 24 września 1975 roku - oraz dwie kopie niedatowanych listów Winowskiej do ks. Chróściechowskiego - pierwszy prawdopodobnie pochodzi z 1969, drugi sprzed 1974 roku.

Z abp. Józefem Gawliną Maria Winowska utrzymywała ożywione kontakty. $\mathrm{Na}$ interesujący nas temat zachował się w archiwum jeden list - abp. Gawliny z 23 stycznia 1959 roku. Sprawy Bożego Miłosierdzia dotyczy także jeden list abp. Karola Wojtyły wysłany do Winowskiej z Rzymu 25 kwietnia 1967 roku. Jest także list pisarki do abp. Antoniego Baraniaka, pisany w 1959 roku w Środę Popielcową, która przypadała wówczas 11 lutego. W spuściźnie Winowskiej zachował się także list od s. Beaty Piekut, datowany 8 lutego 1968 roku, oraz kopia odpowiedzi pisarki z 26 kwietnia 1969 roku.

Większość listów pisana była na maszynie i podpisywana ręcznie przez autorów. Tylko dwa listy - ks. Sopoćki z 28 maja 1958 roku oraz ks. Chróściechowskiego z 24 września 1975 roku - były pisane ręcznie. Listy, co zrozumiałe, mają różną długość: od bardzo lapidarnych (abp. Wojtyły z 25 kwietnia 1967 roku), po kilkustronicowe, np. s. Beaty Piekut (8 lutego 1968 roku), ks. Michała Sopoćki (7 lipca 1959 roku). Winowska listy pisała na maszynie, przez kalkę, kopię zostawiając w swoim archiwum. Wydaje się, że nie była w tym konsekwentna, gdyż z niektórych odpowiedzi wynika, iż listy wysłała, ale kopii brak (np. listu do ks. Sopoćki z 4 marca 1959 roku). Listy Winowskiej nie mają podpisu, a często także wstępnego pozdrowienia, co oznacza, że pisała je ręcznie. W wypadku braku adresata o tym, do kogo list był kierowany, wskazuje adnotacja ołówkiem w lewym górnym rogu pisma. Listy oraz ich kopie, mimo cienkiego papieru przebitkowego, zachowały się w dobrym stanie. W cytowanych w artykule fragmentach listów została zachowana oryginalna pisownia, również podkreślenia i słowa zapisane wersalikami. Skorygowane zostały jedynie błędy gramatyczne (rzadkie), natomiast skróty nazwisk, nabożeństw zostały rozwinięte. 


\section{Korespondencja z ks. Michałem Sopoćka}

Korespondencja Marii Winowskiej z ks. Michałem Sopoćką pochodzi z lat 1958-1959. Niemniej z pierwszego listu Winowskiej ${ }^{14}$ wynika, iż pisali listy jeszcze przed ukazaniem się we Francji biografii s. Faustyny, czyli co najmniej od 1957 roku. Na uwagę bowiem ks. Sopoćki z wcześniejszego listu ${ }^{15}$, iż w książce Winowskiej zamieszczono zdjęcie s. Faustyny, którego on nie zna, ona odpowiedziała z lekkim wyrzutem: „trochę w tym winy Księdza Doktora! Prosiłam w swoim czasie o materiały, zdjęcia itp. Ale rychło zrozumiałam, że zwykła roztropność każe Księdzu Doktorowi zachować dystans w czasie pisania tej książki. Poprzestałam więc na fotografii, jaką dał mi ks. Misiak", czyli zaanagażowany w rozwój kultu Bożego miłosierdzia pallotyn mieszkający we Francji. Winowska przyznała, że żadna książka nie „kosztowała” jej tyle co ta. „Nie wiem, czy miałabym odwage podjać się od nowa podobnej imprezy. Sprawdziłam na własnej skórze słowa Siostry Faustyny «że szatan niczego tak nienawidzi jak Miłosierdzia»".

Winowską i ks. Sopoćkę łączył podobny - krytyczny stosunek do obrazu Jezusa Miłosiernego pędzla Adolfa Hyły. Zdaniem Winowskiej był on „zdradą oryginału”. Pisała: „Obraz Kazimirowskiego jest słaby artystycznie, ale tym bardziej uderza nadzwyczajną precyzją i wiernością dla kanonów ikonograficznych, sięgających najstarszej tradycji (acherotypy)”. Jesienią 1958 roku w związku ze śmiercią Piusa XII oraz konklawe prymas Stefan Wyszyński przebywał w Rzymie od 19 października do 19 grudnia. W tym czasie, 19 listopada, Święte Oficjum przyjęło dekret o objawieniach s. Faustyny Kowalskiej. Kilka miesięcy później Winowska pisała do ks. Sopoćki ${ }^{16}$ : „Wiem, z jakimi gromami wracał Ksiądz Prymas. Prawdę mówiąc nie zrobił nic w Rzymie, żeby burzę zażegnać. Ksiądz arcybiskup Baraniak mocno się przyczynił do werdyktu, gdyż naszczuł konsultora Świętego Oficjum przeciw S. Faustynie.

\footnotetext{
14 AKMKr, Achiwum Marii Winowskiej, List Marii Winowskiej do ks. Sopoćki z 21.06.1958.

15 AKMKr, Achiwum Marii Winowskiej, List ks. Michała Sopoćki do Marii Winowskiej z 27.05.1958.

16 AKMKr, Achiwum Marii Winowskiej, List Marii Winowskiej do ks. Sopoćki, niedatowany. O tym, iż był pisany 4.03.1959, informuje ks. Sopoćko w odpowiedzi z 17.03.1959.
} 
Rzym sądził, że polski Episkopat od tej całej sprawy umywa ręce”. Pisała też, że abp Baraniak nie zgodził się na przesłuchanie i zaprzysiężenie s. Ksawery Olszamowskiej „w sprawie autentyczności modlitwy kard. Hlonda, choć rozesłał okólnik w tej materii"17.

W ocenie Winowskiej „pasem ratunkowym w tej burzy” stała się jej książka, która ma posłużyć do dalszych gruntowniejszych badań. Faktem jest, że pisarka rozesłała swoją książkę do wielu osób w Kościele, w tym w Watykanie. Księdza Sopoćkę informowała też, że „wbrew temu, co ustalił Ks. Prymas, werdykt Św. Oficjum ma charakter lokalny i ostrzegawczy, został skierowany wyłą c znie do tych, którzy popełnili nadużycia. Nie został w ogóle opublikowany i w tej chwili na to się zanosi, że pójdzie «ad acta». Mam w Św. Of[icjum] bardzo serdecznych przyjaciół". Niestety, wiadomości Marii Winowskiej w tym wypadku nie były ścisłe - dwa dni później, 6 marca 1959 roku, została ogłoszona notyfikacja Świętego Oficjum.

Winowska zamierzała poprzez swoje rozległe znajomości doprowadzić do tego, aby Watykan skontrolował tłumaczenie pism s. Faustyny, w których konsultor dopatrzył się „herezji”, gdyż przekład - pisała - został dokonany „przez ludzi świeckich nie mających pojęcia o teologii”. Chciała także doprowadzić „do mianowania specjalnej komisji, która by całą rzecz zbadała”. Za „ciężki grzech” polskiego episkopatu uznała to, iż on takiej komisji nie powołał. „Dążę do tego, żeby cała sprawę wziął w ręce kardynał Tisserand [prefekt Kongregacji Kościołów Wschodnich], żeby z racji soboru powołano komisję mi e s z a n ą teologów obu obrządków, którzy by rozpatrzyli sprawę S. F[austyny]”. Winowska podkreślała, że „w sercu misji S. Faustyny jest obraz Jezusa Miłosiernego”, dlatego należałoby wydobyć analogie między nim a tzw. acherotypami. Zachowana na Wschodzie tradycja ikonograficzna jest bowiem pomostem między chrześcijanami Wschodu i Zachodu.

Ksiądz Sopoćko w trzech listach pisanych do Marii Winowskiej w 1959 roku dotyka kilku kwestii związanych z kultem Bożego miłosierdzia.

${ }_{17}$ O sprawie tej m.in. w E. K. Czaczkowska, Papież, który uwierzył, dz. cyt., s. 51-53. 
W pierwszym liście ${ }^{18}$ tłumaczy, że wiedząc, iż „w Rzymie do objawień prywatnych odnoszą się z wielką rezerwą”, chciał szerzyć kult Bożego miłosierdzia tylko „na podstawie Pisma św., Tradycji i Liturgii, nie ujawniając objawień S. F[austyny]. Tak było do r. 1940. Dopiero wówczas paru księży nakłoniło mnie, bym ujawnił pochodzenie obrazu, a tym samym i objawień S. F[austyny], czego dzisiaj b. żałuję. W r. 1953 cofnąłem się, ale już to nie pomogło".

Ksiądz Sopoćko podkreśla, że jest przekonany o prawdziwości objawień s. Faustyny, ale także i o tym, że kult miłosierdzia Bożego, w tym starania o Święto Bożego miłosierdzia, trzeba oprzeć „wyłącznie na objawieniu publicznym i liturgii”. Oddzielając kult publiczny od prywatnych objawień, przeforsował w Komisji Głównej Episkopatu aprobatę obrazu Jezusa Miłosiernego pędzla Ludomira Ślendzińskiego. Skarży się, że siostry ze Zgromadzenia Matki Bożej Miłosierdzia, a za nimi palottyni i marianie szerzą nadal obraz p. Hyły ,jako rzekomo namalowany według wskazówek S. F[austyny]". Zaś zamieszczenie reprodukcji obrazu Hyły w książce Winowskiej „z zaznaczeniem, że on jest namalowany wg wskazówek S. F[austyny], sprawiło to, że dziś Komisja Gł[ówna] Episkopatu wycofuje swą aprobatę". Ksiądz Sopoćko informuje, iż wręczył prymasowi Wyszyńskiemu podanie, które episkopat miałby skierować do Stolicy Apostolskiej, w sprawie „ustanowienia święta M[iłosierdzia] B[ożego] w związku z Millenium, ale nie wiem, jaki spotkał los jego". Prosi więc Winowską, aby wysondowała, jak takie podanie przyjęłaby kongregacja w Rzymie, jeśli pozytywnie, to - podsuwa myśl - „należałoby jakoś na ks. Prymasa wpłynąć, może przez abp. Gawlinę, by zechciał to podanie, może w formie zmienionej, przedłożyć Episkopatowi do podpisania i przesłania do św. kongeregacji”. Ksiądz Sopoćko konstatuje dalej, iż „sprawa S. F[austyny] poszłaby swoją drogą nieco później. Na razie chodzi głównie o to święto i o uaktywnienie kultu".

18 AKMKr, Archiwum Marii Winowskiej, List Marii Winowskiej do ks. Michała Sopoćki z 17.03.1959. 
Niejako uzupełnieniem tego listu był kolejny ${ }^{19}$, do którego dołączył swój trzystronicowy artykuł w formie maszynopisu pt. Nowenna o miłosierdzie Boże nad światem. Kult Serca Jezusowego a kult Miłosierdzia Bożego, z prośbą, by „gdyby trzeba było”, opublikować go w języku „,czytelnym w kongregacji”. Czyni to, gdyż dochodzą go wieści, że „są usiłowania połączenia kultu miłosierdzia Bożego z kultem Serca Jezusowego z obawy, aby ten pierwszy nie przeszkadzał drugiemu. Nawet ponoć ten dekret między innymi był spowodowany tą obawą". Ksiądz Sopoćko w tym liście odnosi się do pomysłu Winowskiej, aby doprowadzić do powołania komisji, która by raz jeszcze przeanalizowała tłumaczenie Dzienniczka s. Faustyny. Pisał: „dekret Św. Oficjum w sprawie Mił[osierdzia] Boż[ego] nie ulegnie zmianie, dopóki żyją ci, którzy go wydali, choćby nawet rewizja tłumaczenia Dzienniczka S.S.[sióstr ze ZMBM] spowodowała poprawienie błędów. Zresztą mamy możność szerzenia kultu Mił[osierdzia] $\mathrm{B}$ [ożego] niezależnie od prywatnych objawień i tę możność należałoby teraz wykorzystać".

Maria Winowska na pewno odniosła się do opinii ks. Sopoćki, bo choć w jej archiwum nie zachowała się kopia takiego pisma, to kolejny list ks. Sopoćki ${ }^{20}$ jest odpowiedzią na zarzuty Winowskiej. Pisarka, wynika z odpowiedzi księdza, krytykowała ks. Sopoćkę, iż odcina się od s. Faustyny. Było to mocnym i zapewne bolesnym zarzutem postawionym człowiekowi, który rozpoznał prawdziwość objawień s. Faustyny, pomógł jej w przekonaniu o tym przełożonych zgromadzenia, angażując się na resztę życia w szerzenie kultu Bożego miłosierdzia.

Ksiądz Sopoćko przypominał, że „przeżyć Siostry Faustyny” nie można „nazywać objawieniem prywatnym, dopóki Kościół nie zezwoli. Dlatego prawdą jest, że «obraz Najm[ilszego] Zbawiciela nie ma nic wspólnego z objawieniem prywatnym», jak zaznaczyłem w liście poprzednim. Może to być wizja artystyczna, którą jako taką p. Kazimirowski przelał na płótno wg wskazówek S. F[austyny]. Ja «nie musialem odcinać się

19 AKMKr, Archiwum Marii Winowskiej, List ks. Michała Sopoćki do Marii Winowskiej z 23.04.1959.

20 AKMKr, Archiwum Marii Winowskiej, List ks. Michała Sopoćki do Marii Winowskiej z 7.07.1959. 
od S[iostry] F[austyny] przez posłuszeństwo», albowiem nigdy swej działalności nie opierałem na jej przeżyciach, które były tylko okazją dla moich osobistych przeżyć, pobudzających do studiów i rozważań [...]. Słuszne stanowisko biskupów nie wpłynęło na mnie, a tylko utwierdziło w powziętym wcześniej”. Ksiądz przywołał także postać kard. Augusta Hlonda, który podzielał opinię, iż nie należy łączyć i opierać „starań o święto M[iłosierdzia] B[ożego] z przeżyciami S.F[austyny], albowiem one wzajemnie sobie przeszkadzają". Polecił nawet księdzu najpierw „przygotować grunt przez rozprawy teologiczne, gdyż nawet cuda na razie nie będą brane pod uwagę do ustanowienia święta”. Ksiądz Sopoćko podkreślił też, że nic nie stoi na przeszkodzie, by on starał się o jedno - święto, a siostry ze ZSMBM o drugie - beatyfikację s. Faustyny. „Beatyfikacja S.F[austyny] (jak to widać na innych kandydatach) potrwa długo, a święto Mił[osierdzia] B[ożego] nie cierpi zwłoki”.

Ciekawa jest informacja, iż prymas Wyszyński przed ukazaniem się dekretu Świętego Oficjum obiecał ks. Sopoćce wprowadzić kult Bożego miłosierdzia do Wielkiej Nowenny. Po dekrecie, zauważył ks. Sopoćko, „raczej nie będzie miał odwagi, albowiem radził, by nawet teologicznie tej sprawy nie ruszać”. Biorąc pod uwagę, iż wiosną 1957 roku biskupi negatywnie odpowiedzieli na pytania watykańskiej ankiety o rozwój kultu Bożego miłosierdzia, taka obietnica wydaje się mało prawdopodobna ${ }^{21}$.

$\mathrm{Na}$ tym być może zakończyła się korespondencja Winowskiej i ks. Sopoćki, którzy, jak pokazują listy, różnili się w opinii co do łączenia objawień prywatnych s. Faustyny z kultem Bożego miłosierdzia oraz tego, co jest w centrum misji s. Faustyny.

${ }^{21}$ O wynikach ankiety przekazanej do Watykanu w maju 1957 roku zob. E. K. Czaczkowska, Papież, który uwierzyt, dz. cyt., s. 39-44. 


\section{List abp. Józefa Gawliny}

Arcybiskup Józef Gawlina w sprawie kultu Bożego miłosierdzia pisał do Marii Winowskiej w styczniu 1959 roku $^{22}$, odpowiadając na jej pismo z 19 stycznia. Podzielił się przypuszczeniem, iż „sprężyną”, wydania przez Święte Oficjum dekretu był „o. Balić, może pod namową ks[iędza] arcybiskupa Baraniaka". Informował też, że wbrew doniesieniom Winowskiej, „nie było w Polsce żadnej komisji badań na temat Siostry Faustyny”, od prymasa Wyszyńskiego dowiedział się, iż „komisja biskupów polskich zbadała tę sprawę i uznała objawienia Siostry Faustyny nie jako nadprzyrodzone. Być może, że Św. Officium na badaniach tych oparło swoje orzeczenie".

Nazwisko o. Karola Balića, chorwackiego franciszkanina, konsultora Świętego Oficjum w listach Winowskiej powtórzy się jeszcze kilkakrotnie.

Z listu abp. Gawliny wynika, iż adresatka informowała go o zamiarze napisania do abp. Antoniego Baraniaka, co on odradzał. „Może się usztywnił po przeczeniu Św. Officium. Jestem zdania, że sprawa zwycięży, ale suo tempore. Na razie trzeba to przyjąć jako dopust Boży, a w międzyczasie przygotować uczciwe tłumaczenie pism Siostry Faustyny. Osobiście uważam, że bezzwłoczna reakcja mogłaby, mówiąc po rzymsku, być źle tłumaczona".

\section{List do abp. Antoniego Baraniaka}

Wbrew radom abp. Gawliny Winowska napisała do abp. Baraniaka ${ }^{23}$. Krytyczna wobec działań adresata, mających wpłynąć na decyzję Świętego Oficjum, w piśmie skierowanym do niego nie wyraziła tego wprost. Przyjęła inną taktykę. Pisała: „od jakiegoś czasu krąży na Zachodzie ohydna plotka, którą na gwałt należy sprostować. Ponieważ

22 AKMKr, Archiwum Marii Winowskiej, List abp. Józefa Gawliny do Marii Winowskiej z 23.01.1959.

23 AKMKr, Archiwum Marii Winowskiej, List Marii Winowskiej do abp. Antoniego Baraniaka, Środa Popielcowa [11.02.]1959. 
zasięg jej wzrasta, obiecałam zwrócić się wprost do Ekscelencji z prośbą o stwierdzenie czarno na białym, że to potwarz [...]. Opowiada się mianowicie, i to nagminnie, że to Ekscelencja w zeszłym roku był u Ojca Balića, konsultora Świętego Oficjum, żeby «wykończyć» Siostrę Faustynę i namówić do dekretu «likwidującego» całą tę sprawę". Winowska zapewnia, że broni arcybiskupa ze wszystkich sił, ale „przydałby się list w tej materii, przecinający wszelkie wątpliwości”, ten zarzut, jakoby „ktoś z naszych najdroższych biskupów grał rolę hamującą w tej wielkiej ofensywie modlitw do Pana Miłosiernego, która dziś już obejmuje cały świat”. Po czym powtarza pytanie, które - jak twierdzi zadał jej ktoś z hierarchów we Francji, na które ona nie potrafi odpowiedzieć, a mianowicie: „Czy sprawę S. Faustyny zbadała wyznaczona w tym celu komis ja te olo gó w?" Tak jak to się działo na zachodzie przy okazji innych objawień. „Nie umiałam odpowiedzieć, czy nasz episkopat wyznaczył dla tej sprawy komisję kanoniczną, ale podejrzewam, że nie, gdyż w takim razie nie byłoby przecież nieporozumień na temat autentyczności modlitwy świętej pamięci kardynała Hlonda w sprawie beatyfikacji S. Faustyny". Winowska przy okazji wspomina, jakoby ktoś jej mówił, że na soborze sprawą obrazu Jezusa Miłosiernego zajmie się komisja obrządków wschodnich. Nie wiadomo, czy nie wspomniała abp. Baraniakowi, że ona prowadzi w tym kierunku działania, lub też ks. Sopoćce, o czym było wyżej, że to nie jej pomysł? Na soborze żadna komisja obrazem Jezusa Miłosiernego się nie zajmowała, ale rozmowy na temat kultu były prowadzone w kuluarach ${ }^{24}$.

Na koniec, już po oficjalnym, pokornym pożegnaniu dodała, że, oczywiście, gdyby siostra Faustyna „była heretyczką, należałoby ją zdemaskować. Czy można jednak uważać za błąd ufność w Boże Miłosierdzie, które jest sednem jej «misji»? Nawet gdyby jej objawienia były błędne, ufność nie jest błędem. Nawet gdyby była «histeryczką», owoce tej «histerii« są błogosławione, gdyż bronią przed rozpaczą. Dlatego nie wierzę, żeby Ekscelencja zajął w tej sprawie oficjalnie negatywne stanowisko, gdyż zanadto ufam roztropności najmilszego Syna kardynała Hlonda,

24 Zob. M. Białkowski, Protokoły konferencji polskich ojców soborowych. Zbiór dokumentów 1962-1965, Lublin 2018 [w druku]; E. K. Czaczkowska, Papież, który uwierzył, dz. cyt., s. 60-63. 
który zawsze powtarzał, że nie wolno sądzić, jeśli się nie zna na wylot całoks ztałtu danej sprawy".

W spuściźnie Winowskiej nie ma odpowiedzi abp. Baraniaka.

\section{List abp. Karola Wojtyły}

Sprawa tłumaczenia na język polski biografii s. Faustyny pióra Marii Winowskiej ciągnęła się przez kilka lat, a omówienie przyczyn tego wymagałoby odrębnego artykułu. Jednym z podstawowych warunków publikacji było uzyskanie zgody kurii watykańskiej. Tego właśnie dotyczył list abp. Karola Wojtyły do Marii Winowskiej ${ }^{25}$, będący odpowiedzią na jej pytanie. Metropolita krakowski pisał: „w czasie audiencji udzielonej mi przez Jego Eminencję Kardynała Ottaviani[ego], Pro-Prefekta Świętej Kongregacji Doktryny Wiary, dnia 22 kwietnia br., podniosłem potrzebę tego rodzaju publikacji w naszym języku; Jego Eminencja wyraził na to swoją zgodę".

Książka Marii Winowskiej ukazała się w Polsce siedem lat później, w 1974 roku.

\section{Korespondencja z s. Beatą Piekut ZSMBM}

Ciekawych informacji dostarcza list s. Beaty Piekut do Marii Winowskiej ${ }^{26}$. Powodem nawiązania kontaktu s. Piekut z Winowską było polskie tłumaczenie biografii s. Faustyny, które do niej dotarło w formie maszynopisu. Zakonnica, która od 1964 roku zajmowała się w zgromadzeniu sprawą s. Faustyny, przyznała w liście, iż pomimo nacisków - nie pisze, z czyjej strony - „wiedziona jakąś intuicją” nie zgodziła się skorzystać

25 AKMKr, Archiwum Marii Winowskiej, List abp. Karola Wojtyły do Marii Winowskiej z 25.04.1967.

26 AKMKr, Archiwum Marii Winowskiej, List s. Beaty Piekut do Marii Winowskiej z 8.02.1968. 
z doświadczeń swej poprzedniczki, czyli m. Ksawery Olszamowskiej. „Odcięłam się zupełnie od wszystkiego i całkowicie zaufałam Bogu”.

Siostra Piekut prosi Winowską, aby nie używać w książce słowa „zeznania”, ale „wspomnienia, relacje”, gdyż o nie w istocie chodzi; zeznania składa się w procesie, a te, dodajmy, do momentu ogłoszenia beatyfikacji są tajne. Prostuje informację, iż w zgromadzeniu mają tylko ,jedno, i to w grupie” zdjęcie s. Faustyny. Ale najważniejsza sprawa dotyczy „,czytania przez s. Faustynę mistyków". Winowska powołała się w książce na list m. Ksawery Olszamowskiej z 22 lipca 1957 roku ${ }^{27}$, w którym zakonnica w odpowiedzi na pytania pisarki stwierdziła, że s. Faustyna po pierwsze, nigdy nie czytała ani Dziejów duszy św. Teresy od Dzieciątka Jezusa, ani dzieł św. Jana od Krzyża, czy św. Teresy z Ávili. Po drugie, nie miała mszału, a jedynie Nowy Testament, po trzecie zaś, ulubioną jej lekturą był Żywot siostry Benigny Konsolaty Ferrero, czyli włoskiej zakonnicy, która w objawieniach Jezusa otrzymała orędzie o Bożym miłosierdziu. To świadectwo $\mathrm{m}$. Ksawery było istotne, gdyż, jak zauważyła w książce Winowska, ono „wyklucza wszelkie wpływy i reminiscencje, może podświadome" s. Faustyny odnośnie do objawień Jezusa o Bożym miłosierdziu.

"A teraz dajmy świadectwo prawdzie" - napisała s. Beata Piekut, która - przypomnijmy - dwa lata młodsza od s. Faustyny, do zgromadzenia wstąpiła siedem lat po niej, w 1932 roku. Mistrzynią w nowicjacie s. Beaty i s. Faustyny była m. Maria Józefa Brzoza ${ }^{28}$. Dlatego s. Piekut pisze, iż „wie z doświadczenia”, że m. Józefa dawała książkę Dzieje duszy św. Tereski od Dzieciątka Jezus „do czytania indywidualnego, a nawet była ona czytana na wspólnych czytaniach". I dodaje, że skoro s. Faustyna, jak wspomina w Dzienniczku, miała do św. Teresy wielkie nabożeństwo przed wstąpieniem do zgromadzenia, to trudno przyjąć, że nie interesowała się jej Dziejami duszy.

„Czy nigdy nie czytała dzieł św. Jana od Krzyża i św. Teresy? Może tak, a może i nie. Siostry starsze ode mnie, które bliżej znają S. Faustynę, nie twierdzą wyraźnie, że nie czytała. Raczej są skłonne uważać, że właśnie czytała. Z listów, jakie miałam możność przejrzeć kilka dni temu, pisanych

27 M. Winowska, Prawo do miłosierdzia. Posłannictwo Siostry Faustyny, Paryż 1974, s. 39.

28 E. K. Czaczkowska, Siostra Faustyna, dz. cyt., s. 182. 
na zlecenie s. Ksawery w tej sprawie, nie wywnioskowałabym, że «nigdy nie czytała». A więc skąd takie twierdzenie? Czy nie subiektywizm i tendencja?” Co do mszału z kolei, to s. Beata wspomina, iż m. Józefa dała jej mszał, mimo iż o niego nie prosiła. Dlatego zadaje w liście pytanie: „Czy więc Matka Maria Józefa, znając duchowość S.F[austyny] nie mogła jej także dać mszału? To znaczy nie ręczę, że tak było, ale możliwość była”. I wreszcie sprawa „ulubionej lektury” s. Faustyny. Siostra Beata twierdzi, że mistrzyni nowicjatu m. Józefa Brzoza dawała tę książkę „wszystkim bardziej zaawansowanym duchowo nowicjuszkom”. Czytały ją s. Piekut i wiele innych sióstr. Siostry współczesne s. Faustynie „mogły powtórzyć, że czytała taką książkę, ale nie spotkałam twierdzenia, że Życie Siostry Benigny Konsolaty było ulubioną lekturą S.F[autyny]".

Siostra Beata tłumaczy, że za swój obowiązek uznała zasygnalizowanie spraw, które uważa „za niezgodne z prawdą, czy też niebezpieczne. Jeżeli po latach próby wyprowadzamy sprawę na czyste fale, musimy być bardzo uważne i ostrożne”. Zastrzega też, że m. Ksawera „na pewno «chciała dobrze», ale czy czyniła dobrze? - Zdaje mi się, że pełnym dobrem, to p rawda. A jeżeli jej nie znamy, nie powinniśmy stawiać twierdzeń".

Z lektury polskiego tłumaczenia biografii s. Faustyny, która ukazała się w 1974 roku, wynika, iż Maria Winowska częściowo tylko wzięła pod uwagę uwagi s. Piekut. Wprawdzie zmieniła zdanie z pierwotnej wersji: „siostra Faustyna nigdy nie czytała mistyków” (cytat z listu s. Piekut) na „Siostra Faustyna nie znała teologów mistycznych”29, ale znaczeniowo zmiana nie była wielka. W przypisie zostawiła też cytat z listu m. Ksawery Olszamowskiej z lipca 1957 roku, ale w ostatnim jego akapicie dodała: „Siostry zajmujące się ostatnio sprawą siostry Faustyny skłonne są przypuszczać, że niejakie wpływy lektur mogły istnieć dzięki mistrzyni nowicjatu, która miewała konferencje dla swych nowicjuszek" ${ }^{30}$. Natomiast w epilogu książki powtórzyła, iż s. Faustyna nie miała mszału ${ }^{31}$.

\footnotetext{
M. Winowska, Prawo do miłosierdzia, dz. cyt., s. 39.

M. Winowska, Prawo do miłosierdzia, dz. cyt., s. 39.

M. Winowska, Prawo do miłosierdzia, dz. cyt., s. 273.
} 
Maria Winowska w odpowiedzi ${ }^{32}$, którą napisała dopiero rok później, przyznała, że nie jest zadowolona z polskiego tłumaczenia biografii, które powinno zostać poprawione. Jednocześnie poprosiła siostrę o skorygowanie błędów w maszynopisie tłumaczenia i odesłanie tekstu. Chciała też, aby polskie tłumaczenie ukazało się za jej aprobatą. Przy okazji dowiadujemy się, że m. Ksawera Olszamowska była dla Winowskiej przy pisaniu książki ,jedynym źródłem informacji, uzupełniających otrzymane materiały".

Winowska streściła też s. Piekut zdarzenie, które było jej udziałem w kurii watykańskiej i które powtórzyła kard. Wojtyle, a o którym pisała też m.in. do ks. Chróściechowskiego ${ }^{33}$. Otóż przed wydaniem we Francji w 1958 roku biografii s. Faustyny maszynopis książki dała do czytania o. Reginaldowi Garrigou Lagrange'owi, francuskiemu dominikaninowi, który był konsultorem Świętego Oficjum. Przy następnej wizycie w Watykanie usłyszała od o. Lagrange'a: „Szykuje się atak na Siostrę Faustynę w Świętym Oficjum! Niech pani pójdzie do Ojca Balića i spróbuje go nawrócić. [...] więcej powiedzieć nie mogę". Poszła więc do o. Balića, którego znała. „Kiedy jednak poruszyłam sprawę Siostry Faustyny, zesztywniał nagle i powiedział dosłownie tak [...]: «Allora noi (przy czym wskazał na mnie palcem), noi che ci priviamo di tut to, saremo trattati della stessa maniera com [poprawione piórem] tutti questi birboni, mascalzoni, le donne della strada, tutti quanti, chce bastarebbe un ricorso alla divina Misericordia per accommodarlo tutto? Ma chce!!!»”. W polskim wolnym przekładzie znaczy to: „A zatem my, my, którzy pozbawiamy się w s zy s tk i e go, będziemy traktowani w taki sam sposób, jak wszyscy ci hultaje, łajdacy, ulicznice, ci wszyscy, którym wystarczy odwołać się do Bożego Miłosierdzia, żeby wszystko naprawić? Ależ nie!!!”.

Komentarz Winowskiej brzmiał: „wtedy zrozumiałam, jakim zgorszeniem dla faryzeuszów wszystkich wieków jest i będzie Boże Miłosierdzie. W gruncie rzeczy ci, co «potępiali» Siostrę Faustynę,

32 AKMKr, Archiwum Marii Winowskiej, List Marii Winowskiej do s. Beaty Piekut z 26.04.1969.

${ }_{33}$ AKMKr, Archiwum Marii Winowskiej, List Marii Winowskiej do ks. Juliana Chróściechowskiego, niedatowany. 
potępiliby Magdalenę, cudzołożnicę, Zacheusza... dobrego Łotra, tego, którego sam Pan Jezus ukanonizował na krzyżu! Nasze ciasne serca nie mogą pojąć tego nadmiaru Bożej Miłości i pierwszeństwa grzeszników: «celnicy i wsztecznice u p r ze d zą was w królestwie Bożym»... Nie dlatego, że grzesznicy, ale dlatego, że na dnie grzechu olśniło ich, poraziła łaska darmo dana, nieskończone Miłosierdzie".

Czy to zdarzenie i słowa o. Balića spowodowały, iż Winowska nadała biografii s. Faustyny tytuł Prawo do miłosierdzia? Nie można tego wykluczyć.

Znamienny jest też komentarz Winowskiej do działań ks. Sopoćki podejmowanych $\mathrm{w}$ sprawie ustanowienia święta Bożego miłosierdzia, co w jego ocenie mogło nastąpić tylko poprzez oddzielenie kultu Bożego miłosierdzia od objawień prywatnych s. Faustyny. Winowska, krytyczna wobec takiego myślenia, pisała do s. Piekut: „Że też nie pamięta [ks. Michał Sopoćko], co mu mówiła Siostra Faustyna, że się jej «zaprze»! W gruncie rzeczy na jej rożnie chciał czy chce upiec własną pieczeń teologiczną. Tymczasem wszystkie jego traktaty po polsku czy po łacinie zupełnie nie «chwytają». Przecież nie trzeba nawracać Kościół na Boże Miłosierdzie!!! Misja siostry Faustyny na tym polega, żeby tę największą tajemnicę Bożą unaocznić, stwierdzić własnym świadectwem”. Można domyślać się, że w tak zdecydowanym tonie wyraziła swoją opinię we wspomnianym, a niezachowanym liście do ks. Sopoćki, co spowodowało zerwanie między nimi korespondencji.

\section{Korespondencja z ks. Julianem Chróściechowskim}

Sprawa rozwoju kultu Bożego miłosierdzia łączyła Marię Winowską i ks. Juliusza Chróściechowskiego. Z korespondencji wynika, iż listów dotyczących tej sprawy było więcej niż zachowane. W pierwszym z nich ${ }^{34}$ ks. Chróściechowski informuje pisarkę o spotkaniu z abp. Paulem Philippem z Kongregacji Nauki Wiary „w sprawie nabożeństwa”, jak

${ }^{34}$ AKMKr, Archiwum Marii Winowskiej, List ks. Juliana Chróściechowskiego do Marii Winowskiej z 3.12.1967. 
można domniemywać - do Bożego miłosierdzia oraz 10 listopada w USA z jezuitą o. Antonim Mrukiem, wicepostulatorem w procesie beatyfikacyjnym s. Faustyny Kowalskiej. Ojciec Mruk oświadczył, iż z uwagi na obowiązywanie dekretu Świętego Oficjum należy traktować „oddzielnie sprawę świętości s. Faustyny i sprawę jej widzeń”. Pisał też: „Kard. Ottaviani najwidoczniej nie sprzeciwiał się procesowi [beatyfikacyjnemu], wychodząc ze słusznego założenia, że tego rodzaju proces może tylko rzucić światło na sprawę, ale nie oznacza przekreślenia przez niego dekretu". Zastanawia się także nad pytaniem zadawanym w tej sytuacji pewnie przez samą Winowską, a mianowicie: „W jakiej tedy mierze i jakim sposobem nowe wydanie książki może zawierać objawienia przypisywane s. Faustynie? Jeśli natomiast ograniczyć się do samego życiorysu (bez objawień), to książka będzie bardzo niepełna, aczkolwiek napisanie takiej książki jest możliwe i może dzisiaj właśnie jedynie bezpieczne”. W kolejnym krótkim piśmie ${ }^{35}$ ks. Chróściechowski poprosił Winowską o opinię na temat czterech swoich artykułów o Bożym miłosierdziu i procesie beatyfikacyjnym s. Faustyny. W odpowiedzi ${ }^{36}$ Winowska bardzo krytycznie odniosła się do opinii i działań adresata, którego tytułuje „Paziem Siostry Faustyny”, co z jednej strony wkazuje na bliższą ich znajomość, ale też protekcojonalizm pisarki. Księdzu Chróściechowskiemu Winowska zarzuciła, że jest pod wpływem myślenia ks. Sopoćki, który oddziela sprawę Bożego Miłosierdzia od objawień s. Faustyny. „Tymczasem chodzi o coś zupełnie innego. O sprawę Siostry Faustyny! Kardynał Wojtyła wziął ją do serca. Proces [beatyfikacyjny] idzie dobrze. Kardynał Ottaviani jak najbardziej zgodził się na opublikowanie polskiej biografii, a więc tłumaczenia mojej książki”. Powtórzyła też to, co pisała w liście do s. Piekut, że ks. Sopoćko s. Faustyny „się oficjalnie wypiera”, gdy ,jest jasne jak słońce”, że „nigdy by nie pisał tyle o Bożym Miłosierdziu, gdyby jej nie spotkał”. Powtórzyła też krytyczną opinię o tekstach ks. Sopoćki: „[...] te wszystkie traktaty teologiczne po polsku i po łacinie Księdza Sopoćki

35 AKMKr, Archiwum Marii Winowskiej, List ks. Juliana Chróściechowskiego do Marii Winowskiej z 21.04.1969.

${ }^{36}$ AKMKr, Archiwum Marii Winowskiej, List Marii Winowskiej do ks. Juliana Chróściechowskiego, niedatowany. 
wysyłane do Ojców Soboru i gdzie się dało, nie budziły najmniejszego echa i były nieraz rzucane do kosza po przejrzeniu kilku stron. Niełatwy styl scholastyczny, niełatwy i niepiękny styl w ogóle Księdza S[opoćki] utrudnia lekturę". Winowska zarzuciła też ks. Chróściechowskiemu, że pisze jak w czasach przed soborem watykańskim II, który przecież zreformował Święte Oficjum. Z Watykanu powiał „inny wiatr i dawne gromy Świętego Oficjum idą po prostu do archiwów. W tej perspektywie artykuły Księdza, obawy że owe «anathema» ma moc obowiązującą dziś jeszcze, są wręcz nierzeczowe. Oczywiście, żaden episkopat świata nie ogłosi tego, co myśli. Po prostu i zwyczajnie obchodzi się dawne ukazy za zgodą kard. Šepera [prefekta Kongregacji Nauki Wiary] i obecnej ekipy”. W jej ocenie z racji likwidacji Świętego Oficjum „owe constat de non supernaturalitate reveloationum Soris Faustinae jest szczytem faryzejskiej arogancji”. Winowska wie, że „niepodobna kanonizować S. Faustyny «bez objawień»! Ale niechże Ksiądz się nie spodziewa jakiegoś «odwołania» albo «sprostowania» werdyktu Świętego Oficjum! W Kościele Bożym obowiązuje postawa synów Noego, a więc... Miło si er dzi e. Po prostu werdykt ten zostanie pominięty i ominięty, «jakby go nie było». Dziś kruszyć kopie «contra» jest czymś zbytecznym i niepoważnym". Winowska pomyliła się w opinii, iż werdykt ten zostanie pominięty i ominięty „jakby go nie było”. 15 kwietnia 1978 roku Kongregacja Nauki Wiary wydała dekret uznający decyzję Świętego Oficjum w sprawie objawień s. Faustyny Kowalskiej za nieaktualną ${ }^{37}$.

Winowska powtórzyła także ks. Chróściechowskiemu to, co usłyszała od o. Balića przed publikacją biografii s. Faustyny, a co opisała także w liście do s. Piekut. Nie znamy odpowiedzi ks. Chróściechowskiego na ten list Winowskiej. Ale w kolejnym zachowanym ${ }^{38}$, do którego dołączył obrazki z wizerunkami Jezusa Miłosiernego według Eugeniusza Kazimirowskiego oraz Ludomira Ślendzińskiego, napisał krótko: „Opublikowanie przez Sz. Panią artykułu o właściwym obrazie byłoby

37 P. Socha, Rozwój nabożeństwa do Miłosierdzia Bożego w nowej formie w Polsce i zagranica, w: Wobec tajemnicy Bożego Miłosierdzia, Poznań 1991, s. 206.

38 AKMKr, archiwum Marii Winowskiej, List ks. Juliana Chróściechowskiego do Marii Winowskiej z 20.01.1970. 
niezwykle pożądane, gdyż pod tym względem panuje wielka ignorancja i nie jest wykluczone, że w razie uchylenia wszelkich zakazów mógłby wrócić obraz niewłaściwy (profesora Hyły ${ }^{39}$ )”. W sprawie obrazu Jezusa Miłosiernego Maria Winowska, ks. Sopoćko i ks. Chróściechowski zgadzali się, iż najlepiej postać Jezusa oddaje Kazimirowski.

Winowska skarżyła się adresatowi z Londynu ${ }^{40}$, iż „od lat ciągnie się sprawa tłumaczenia” jej książki o s. Faustynie. Niebawem wyjdzie nowe wydanie francuskie, a tymczasem „eritas gra na niezrozumiałą zwłokę. Przed 5 laty przysłał mi Dłużniewski [Wojciech, wydawca] tłumaczenie swojej kuzynki p. Marii Wierzbickiej, której prawdopodobnie chciał pomóc". Winowska uznała, iż tłumaczenie nie nadaje się do druku, także to, które przedstawiono jej ponownie w „kilku miejscach poprawione”. „Noszę się więc z myślą wydania książki gdzie indziej” - pisała, dopytując się o wydawnictwo pallotynów w Paryżu. Istotnie, tam w 1974 roku wyszło pierwsze polskie wydanie biografii s. Faustyny. Do ks. Chróściechowskiego pisała też, że „najważniejsza ikona obraz Chrystusa Miłosiernego [...] obraz musi być zgodny z «prototypem» (oczy spuszczone, nie mi otła biało-czerwona, a dyskretne strugi krwi i wody). Proszę mi wierzyć, dopóki ta sprawa nie będzie uregulowana, wszystkie nasze starnia spalą na panewce".

W ostatnim zachowanym liście ${ }^{41}$ odręcznie napisanym ks. Chróściechowski gratulował Winowskiej wydania książki o s. Faustynie w językach niemieckim, francuskim i polskim. „Ta rzecz była b. potrzebna i wypełnia ona lukę w szerzeniu się nabożeństwa do Miłosierdzia Bożego".

\section{Podsumowanie}

Korespondencja Marii Winowskiej z lat 1958-1975 w sprawie kultu Bożego miłosierdzia jest interesującym przyczynkiem do historii

\footnotetext{
39 W oryginale w tym miejscu i innych błędnie: Hyli.

${ }^{40}$ AKMKr, archiwum Marii Winowskiej, List Marii Winowskiej do ks. Juliana Chróściechowskiego, niedatowany.

${ }^{41}$ AKMKr, archiwum Marii Winowskiej, List ks. Juliana Chróściechowskiego do Marii Winowskiej, 24.09.1975.
} 
kultu Bożego miłosierdzia w formach podanych przez s. Faustynę Kowalską. Wprawdzie dzisiaj o rozwoju tego kultu wiemy już sporo ${ }^{42}$, niemniej informacje zawarte w listach stanowią ciekawe ich uzupełnienie. Obok informacji o charakterze przyczynkarskim są też wiadomości nowe czy też dotąd publicznie nieujawniane, jak np. opinia o. Karola Balića, konsultora Świętego Oficjum na temat objawień s. Faustyny. Listy są świadectwem czasu - zmagań czcicieli Bożego miłosierdzia o wprowadzenie tego kultu do Kościoła w sytuacji obowiązywania notyfikacji Świętego Oficjum z 6 marca 1959 roku. Opinie wyrażane w listach są, oczywiście, subiektywne, zweryfikowane przez czas, niekiedy - np. w przypadku opinii Marii Winowskiej na temat działań i tekstów ks. Michała Sopoćki - jak się wydaje, krzywdzące. Dokumenty ukazują też różnice między Marią Winowską a ks. Sopoćką, częściowo ks. Julianem Chróściechowskim w ocenie, jak w sytuacji notyfikacji Świętego Oficjum działać na rzecz rozwoju kultu.

${ }^{42}$ Spośród wielu pozycji zob. m.in. E. K. Czaczkowska, Papież, który uwierzył. Jak Karol Wojtyła przekonał Kościót do kultu Bożego Miłosierdzia, Kraków 2016; A. Witko, Święta Faustyna i Miłosierdzie Boże, Kraków 2007; P. Socha, Rozwój nabożeństwa do Miłosierdzia Bożego w nowej formie w Polsce izagranica, w: Wobec tajemnicy Bożego Miłosierdzia, Poznań 1991; A. Mruk, Trudna droga procesu beatyfikacyjnego Sługi Bożej siostry Faustyny Kowalskiej, w: Posłannictwo Siostry Faustyny, Kraków 1991; P. d'Ornellas, Miłosierdzie kreśli obraz mojego pontyfikatu (Jan Paweł II), Warszawa 2007; P. Szweda, A. Witko, 1001 rzeczy o Miłosierdziu Bożym i św. Faustynie, Kraków 2014. 


\section{Summary}

\section{Kłopoty z kultem Bożego miłosierdzia w korespondencji Marii Winowskiej w latach 1958-1975}

W Archiwum Krakowskiej Kurii Metropolitalnej przechowywane jest prywatne archiwum Marii Winowskiej (1904-1993), wybitnej katolickiej pisarki, działaczki emigracyjnej, przez lata bliskiej współpracownicy prymasa Stefana Wyszyńskiego, autorki m.in. pierwszej biogarfii s. Faustyny Kowalskiej. Wśród dokumentów znajduje się korepondencja $\mathrm{z}$ wybitnymi postaciami Kościoła dotycząca kultu Bożego miłosierdzia $\mathrm{w}$ formach podanych przez s. Faustynę. Omawiane $\mathrm{w}$ artykule listy pochodzą z lat 1958-1975, a ich autorami oprócz Marii Winowskiej są: ks. Michał Sopoćko, abp. Józef Gawlina, abp. Karol Wojtyła, s. Beata Piekut, ks. Julian Chróściechowski. Treść listów pokazuje działania podejmowane przez ich autorów na rzecz wprowadzenia kultu Bożego miłosierdzia do Kościoła, a także różnice między nimi co do sposobów postępowania w sytuacji obowiązywania notyfikacji Świętego Oficjum.

słowa kluczowe: Maria Winowska, korespondencja, Boże Miłosierdzie, s. Faustyna

\section{Problems with the Cult of Divine Mercy in the Correspondence of Maria Winowska Between 1958-1975}

In the Archives of the Krakow Metropolitan Curia, there is a private archive of Maria Winowska (1904-1993). Winiarska was an outstanding Catholic writer, an émigré activist, a long-term collaborator of Primate Stefan Wyszyński, and an author of Sister Faustyna Kowalska's first biography (among other works). Among the documents collected there is a correspondence with the major figures of the Church concerning the worship of Divine Mercy in the forms proposed by Sister Faustina. The letters discussed in the article were written between 1958-1975. Their authors, apart from Maria Winowska, are: fr Michał Sopoćko, Archbishop Józef Gawlina, Archbishop, Karol Wojtyła, Sr. Beata Piekut and fr Julian Chróściechowski. The content of the letters shows the actions taken by their authors to introduce the cult of Divine Mercy into the Church. Simultaneously, the correspondence shows the differences between the authors as to how to do that in the context of the Holy office notification being in operation.

Keywords: Maria Winowska, correspondence, Divine Mercy, s. Faustyna 


\section{Bibliografia}

Białkowski Michał, Protokoły konferencji polskich ojców soborowych. Zbiór dokumentów 1962-1965, Lublin 2018 [w druku].

Boniecki A., Odczyt, którego nie będzie, „Tygodnik Powszechny” (1993) nr 22, s. 6.

Ciereszko H., Życie i działalność księdza Michała Sopoćki (1888-1975). Petna biografia Apostoła Miłosierdzia Bożego, Kraków 2006.

Czaczkowska E. K., Nowe ustalenia w sprawie listów milenijnych biskupów polskich do episkoptów świata. Maria Winowska i kard. Stefan Wyszyński współautorami listów, w: 1966. Milenium Chrztu Polski prymasa Stefana Wyszyńskiego. Perspektywa teologiczno-społeczna, pod red. E. K. Czaczkowskiej, Warszawa 2016, s. 131-150.

Czaczkowska E. K., Maria Winowska - szara eminencja Kościoła, „Gość Niedzielny” (2016) nr 13, s. 24-25.

Czaczkowska E. K., Papież, który uwierzył. Jak Karol Wojtyła przekonał Kościót do kultu Bożego Miłosierdzia, Kraków 2016.

Czaczkowska E. K., Siostra Faustyna. Biografia Świętej, Kraków 2012.

Jędraszewski M., Teczki na Baraniaka, t. 1, Świadek, Poznań 2009.

Józef Feliks Gawlina Biskup Polowy Polskich Sił Zbrojnych, w: Emigracyjna Rzeczpospolita 1939-1990, t. 3. oprac. A. K. Kunert, Warszawa 2002.

Konopkowa H., Marii Winowskiej refleksje nad życiem, http://www.cracovia-leopolis. pl/index.php?pokaz=sylwetki\&id=3 (27.01.2018).

Mruk A., Trudna droga procesu beatyfikacyjnego Stugi Bożej siostry Faustyny Kowalskiej, w: Posłannictwo Siostry Faustyny, Kraków 1991, s. 9-22.

Nowak-Jeziorański J., M. Winowska, Korespondencja 1955-1989, oprac. i wstępem opatrzył A. Nowak, Wrocław 2016.

d'Ornellas P., Miłosierdzie kreśli obraz mojego pontyfikatu (Jan Paweł II), Warszawa 2007. Rottenberg M. K., Aby byli jedno, Warszawa 2005.

Socha P., Rozwój nabożeństwa do Miłosierdzia Bożego w nowej formie w Polsce i zagranica, w: Wobec tajemnicy Bożego Miłosierdzia, Poznań 1991.

Szweda P., Witko A., 1001 rzeczy o Miłosierdziu Bożym i św. Faustynie, Kraków 2014.

Turowicz J., Maria Winowska nie żyje, „Tygodnik Powszechny” (1993) nr 22, s. 1.

Weron E., Cegiełka F., Biuletyn teologii laikatu, „Collectanea Theologica” 52 (1982) 1, s. 137-156.

Weigel G., Kres i poczatek. Papież Jan Paweł II - zwycięstwo wolności, ostatnie lata, dziedzictwo, przeł. M. Romanek, Kraków 2012.

Weigel G., Świadek nadziei. Biografia papieża Jana Pawła II, tłum. M. Tarnowska i in., Kraków 2000.

Winowska J., Maria Winowska, Kraków 1995, mps.

Winowska M., Droit à la miséricorde. Vie et mission de soeur Faustine du Saint Sacrement de Pologne, Paris 1958.

Winowska M., Prawo do miłosierdzia. Posłannictwo Siostry Faustyny, Paryż 1974.

Witko A., Święta Faustyna i Miłosierdzie Boże, Kraków 2007. 